\title{
The Potential of Vā Part 2: Theoretical Frameworks of the Vā
}

\section{Abstract}

The article presented is part of a series of articles that composed an exegesis, submitted in fulfilment of the requirements for the degree of Doctor of Philosophy. The series is a narrative of discovery through practice-led research. Each article reveals its purpose and significance that leads into the next series, which then eventuate to that final design proposal.

The exegesis is presented in this format, to break down the components that assisted in practice-led research. Each article can be read and unpacked on its own as a learning tool. The purpose of this edited series is for the exegesis to be more accessible and adaptable creatively to those being introduced to practice-led research. 


\section{Theoretical Frameworks: Review of literature and knowledge}

This research is positioned in the context of contemporary practice. This article considers other bodies of knowledge that contextualise and contribute to this article. This article outlines the contributions of theorists and academics who have influenced the development of the overall research. In relation to the research question I will discuss six significant subjects:

- Space: The vā - a Sāmoan concept

- My Identity: Fa'aSāmoa

- Standpoint epistemologies

- Diaspora

- Blended Backgrounds: Growing diversity

- Traditional Knowledge: Lalava and lalaga

\section{Space: The vā - a Sāmoan concept}

This section critically analyses the literature on the vā, which is a Sāmoan/Pacific concept that feeds into the subject of indigenous spaces, and also looks specifically at its broader concept in the Pacific. In 1862, vā was defined in Pratt's Grammar and Dictionary of the Sāmoan Language as 'a space between'(Pratt, 1893, p. 216).

The Potential of Vā Part 2: Theoretical Frameworks of the $V \bar{a}$ presents the literature review for the study. Drawing on international literature, five sections are 
explored in relation to space, identity, ethnicity, and the materiality and processes. This section also presents statistical as well as social information from Aotearoa/New Zealand Pacific diaspora to set the context and cultural ideologies that influence this research.

It refers to the space between places or people and 'connotes mutual respect in socio-political arrangements that nurture the relationships between people, places, and social environments' (Sa'iliemanu, 2009, p. 29). The influential definition is from Albert Wendt's (1996) Tatauing the PostColonial Body:

Important to the Sāmoan view of reality is the
concept of Vā or Wā in Māori and Japanese. Vā is
the space between, the between-ness, not empty
space, not space that separates but space that
relates, that holds separate entities and things
together in the Unity-that-is-All, the space that is
context, giving meaning to things. The meanings
change as the relationships/the contexts change. A
well-known Sāmoan expression is 'Ia teu le vā.'
Cherish/nurse/care for the Vā, the relationships.
This is crucial in communal cultures that value
group, unity, more than individualism: who
perceive the individual person/creature/thing in
terms of group, in terms of Vā, relationships
(Wendt, 1996, p. 1).

This quote refers to the art of tatau, or tattoo, from a global perspective (Clayton, 2007). Wendt refers to 'space' as the 'space between' and considers how 
this 'space between' relates to different identities. Spaces of identity merge and as they draw closer together to form relationships with one another. Differences between cultures, families, and traditions are created from the interaction in the relational space, which we become aware of when we draw close.

Wendt suggests that vā is not a vacant space, nor a space that needs to be filled. Wendt further implies that some Westerners tend to think that space is a gap that has to be closed. But there is no empty, separate or closed space. Rather, space is of woven connections - a 'duality of substance and respect' (Wendt, 1996, p. 1), and it provides context and symbolises relationships between people, places and environments. Wendt further discusses the importance of social space, because the Sāmoan sense of self is ultimately relational or communal, rather than individualistic (Sa'iliemanu, 2009).

Wendt's (1996) position has been used widely by scholars in the health sector, including Melani Anae (2009, 2001, 2000, 1998a, 1998b, 1997) in relational education, Karl Pulotu-Endermann (2009) for his Fonofale Health Model, and Karlo Mila-Schaaf (Mila-Schaaf, 2006; Mila-Schaaf \& Hudson, 2009) with regard to perspectives on Pacific mental health. A study of Sāmoan perspectives on mental health and culturally appropriate services in New Zealand reports: 
Sāmoa's traditions and protocols explain the nature of Sāmoan being as that of a relational being, that is, the Sāmoan person does not exist as an individual. There is myself and yourself. Through myself, you are given primacy in light of our collective identity and places of belonging (fa'asinomaga), our genealogical lineage (tupu'aga), and our roles and responsibilities and heritage (tofiga) (Tamasese, Peteru, \& Waldegrave, 1997, p. 28).

The New Zealand/Sāmoan health interpretations employ holistic approaches to Pacific concepts and 'engage a responsible ethic in health institutions, dealing with Pacific population/stake holders' (Refiti, 2008b, p. 1).

Wendt's description of the vā is informed by his Sāmoan heritage, but it is important to note that this concept is just as significant to other cultures in the Pacific. Tongan theorist Ka'ili states:

Va- can be glossed as 'space between people or things'. This notion of space is known in Tonga, Sāmoa, Rotuma, and Tahiti as vā, while in Aotearoa and Hawai'i it is known as wa. Va- (or wa) points to a specific notion of space, namely, space between two or more points (Ka'ili, 2005, p. 89).

The va is pertinent across many Pacific cultures. For instance, in Tongan culture this is known as tauhi $v \bar{a}$. The concept of tauhi vā plays a significant role in the Tongan culture and the identity of Tongan people. The term tauhi vā refers to the art of creating and maintaining beautiful socio-spatial relations 
(vā) through the mutual performance of social duties (Ka'ili, 2008).

In his dissertation Tauhi vā: Creating Beauty through the Art of Sociospatial Relations, Ka'ili (Ka'ili) briefly describes the views of anthropologists who studied the social relationships, social relations, and social space of the vā within Pacific cultures. He notes that Feinberg's (2004) study of the Anutan social structure states that vā means a kinship line. In Anutan society, any set of persons with a common ancestor may belong to the same kinship vā. Furthermore, Shore (Shore) adds to this and mentions vā in his ethnography of Sāmoans. Shore employs vā to conceptualise the Sāmoan notion of personhood. Like Wendt, Shore states that a clue to the Sāmoan concept of being is found in the popular Sāmoan saying teu le vā (take care of the relationship)(Wendt, 1996, p. 1). Shore also notes that although vā refers to relationship, 'it also means space or between' (Shore, 1982, p. 311).

Similarly, linguistic anthropologist Alessandro Duranti records that vā demonstrates both space and relationship for Sāmoans. Duranti translates teu le vā (or teuteu le vā) as 'make the relationship beautiful' (1997, p. 343). His interpretation of teu le vā is important because it highlights vā as a space that is 'aesthetically transformed' (Ka'ili, 2008, p. 19). Duranti further states that teu le vā is a key expression for understanding the collective actions of titleholders in the village meetings in Sāmoa 
(1997, p. 343). Duranti is specific in that vā denotes not only space and relationship but it also means 'interval' and 'between', or the physical space between people or things (Duranti, 1997, pp. 343345).

Jeannette Mageo (Mageo), translates the Sāmoan saying teu le vā as 'decorate the space between'. Mageo (Mageo), in relation to Sāmoan notions of respect, contextualises teu le vā in the following way:

Sāmoan moralism councils respect. One does not action one's own behalf but as an ambassador of one's group; therefore, one gives respect in representative capacity to the ambassadors of other groups. This moral principle is celebrated in the poetic dictum that one should "Teu le vā" (Decorate the space between); The space between signifies A relationship, particularly between groups, and is conceptualized as the center of a circle (Mageo, p. 81).

The analysis by anthropological scholars and their knowledge pertaining to vā has provided meaningful concepts to the creative practice of this research. Anthropologist, Anne Allen, who studied the architecture and social space in Sāmoa, defines teu le vā as 'order the space' or 'adorn the relationship' (Allen, 1993, p. 157). Duranti, Mageo, and Allen show in their translation of teu le vā that vā is a space that is decorated, adorned, or beautified. Their interpretations also suggest the notion that 
teu le vā is a social and artistic process of transforming vā into a harmonious and beautiful social space (Ka'ili, 2008).

The descriptive translations from these anthropologists gives consideration to the literal interpretation, as their interpretation of vā will help form the manifestation of design practice (please refer to article 4 The Potential of Vā Part 4 Methodology of Lala-Vā). Ka'ili further suggests that this is not only a Sāmoan concept but it is connected to all Pacific cultures and values, that is, that the vā signifies a relationship. Sāmoans, as well as other Pacific cultures, think about social relations in spatial means (Ka'ili, 2008).

These different, but in many ways similar, interpretations of vā made me realise, as a researcher and designer, the importance of stating my own standpoint, that is, where I position myself. Wendt (1999), I believe, is correct when he explains that the vā is not empty space, but space that relates. However, there may be problems with his notion of between-ness. While vā is activated within the subject in the presence of 'at least two' (Wendt, 1996 , p. 1), it is also a spiritual embodiment in us all. We not only carry this vā within ourselves, but it is embodied in our proper and improper behaviours. Food division and distribution, sleeping and sitting arrangements, and language usage in private and public spaces are all conceived through the vā (Lilomaiava-Doktor, 2009). There are also 
personal and group responsibilities, which maintain balance and agreement in the vā, thus providing social cohesion. All of this can be linked to Sāmoan epistemology. In an interview conducted by $\mathrm{Dr}$ Sa'iliemanu Lilomaiava-Doktor with Aumua Mataitusi Simanu, who is a Professor of Sāmoan Studies at the University of Hawai 'i, Mānoa, Simanu says:

\begin{abstract}
Vā is the most significant concept to understand the complexity of Sāmoan social interactions between people, church, and the environment. It underpins all epistemologies of participation, obligation, and reciprocation that guide our interactions and continue even as Sāmoans move abroad. Performances of social responsibilities and obligations prescribed in Vā rest on the knowledge of social and genealogical connections that 'aiga members possess (Aumua Mata'itusi Simanu, 2006, quoted in Lilomaiava- Doktor, 2009, p. 14).
\end{abstract}

Simanu explains how the relationships between Sāmoan people have great influence in social interactions. Their social interactions are a way in which Sāmoans view their understandings of one another, and behave in a way that is expected, in accordance with their roles and responsibilities. Albert Refiti describes the vā as a co-openness (Refiti 2008, personal communication). Refiti contradicts Wendt (1996) to an extent when referring to the example of a meeting of Sāmoan chiefs (fono). 
When Sāmoan chiefs encounter each other in the fono council they don't think strategically about their vā as a between thing - no, they are already in it, they are seized by it and therefore a beingSāmoan can be said to be already opened. There is no gap, when a matai sits in the fono council he/she is no longer what he/she is today, he/she becomes the ancestor. This is what I mean by a coopenness (Refiti, 2008a, personal communication)

Refiti goes on to say that the vā changes depending on the context of the relations and therefore has a temporal aspect. He supports I'uogafa Tuagalu (2009) who specifically examines vā from a New Zealand perspective, attempting to adapt it in 'context to Sāmoa notions of Vā Fealoaloa'i (relational space) and Vā Tapua'i (sacred/worship space)' (Tuagalu, 2009, p. 108).

Tuagalu (2009), in his article Heuristics of the Vā, suggests that Wendt's widely used definition has a commonality with a theory of social action that is being developed in New Zealand by Sāmoan scholars. They all deal with a notion of the vā as a holistic identity formation predicated on cobelonging and relationship building' (Refiti, 2008b). The active character of the vā becomes desirable when applied as a strategic concept 'creating space for mutual respect' (Anae, 2001, p. 4).

The vā in Sāmoa social structure begins from one's identity. It is referred to as fa'asinomaga (identity). According to Aiono (Aiono) 'the Socratic maxim to 'know thyself', the beginning of all knowledge (poio) 
is knowledge of oneself' (Aiono, 1997, p. 6). Fa'asinomaga, Aiono (Aiono) explains, that fa'asinomaga is founded on three main poles (poutu toa): 'firstly, matai, chiefly titles to which one has genealogical ties; secondly, the land (eie'eie ma fanua), that is attached to those titles; and, lastly, the Sāmoan language, gagana Sāmoa' (Aiono, 1997, p. 6). The Sāmoan language is regarded as the 'fundamental way in which Sāmoans differentiate themselves from other Sāmoans and non-Sāmoans' (Tuagalu, 2009, p. 111).

The vā is important to this research because it helps us understand the complexity of identity for Pacific peoples, as it provides context and symbolises relationships between people, places and environments. Wendt (1996) further discusses the importance of social space, because the Sāmoan sense of self is ultimately relational or communal, rather than individualistic (Lilomaiava-Doktor, 2009).

I acknowledge that my participants from many parts of the Pacific have different interpretations of the vā that add value to the research and stimulate discussion. Epistemologically, vā is encoded with respect, service, and hospitality in maintaining and retaining 'aiga status and a socially well-located family (Lilomaiava-Doktor, 2009). It is important for me to acknowledge and adhere to the variety of references to such a relational space-for example, the gap between cultures, a space within, a third 
space, the space to which things are brought back, a different context, the liminal space-which in turn gives rise to a variety of parallel characterisations: interface, limen, vā (Whimp, 2009). This importance is further examined within traditional constructs of space in the Pacific. A look at indigenous spaces conceptualised within vā, specifically the 'Ha'amonga 'a Maui', was the next point of observation. I choose to investigate this as the physical landmark as vā is said to derive from chiefly systems, which references to Refiti's (Refiti) chief's encounter.

Ha'amonga 'a Maui, meaning Maui's burden is a historical site in Tongatapu. It consists of three coral slabs, two vertical slabs holding the third across. There are many theories about this historical site, however, the theory that has relevance to this research is from Pilimilose Jr Manu's (2013) thesis. He states:

One theory implies that it was the gateway to the royal compound and another that it was used for astronomical purposes. Long before the arrival of the missionaries, Tongans believed in Pacific Gods and spirits. Maui was one of those Gods who was said to have pulled the Pacific islands out of the sea with a hook. It was also said that Maui was under pressure by his task, with the weight of the heavens, sky and other planets placed on his shoulders. The structure appears as a person with a heavy burden. Hence the naming of the structure, Maui's burden (Manu, p. 13). 
Following a discussion regarding the vā with his grandmother, Manu (2013) explains how the Ha'amonga is a symbolic metaphor, which fits well with the concept of vā relationships:

She suggests that the Ha'amonga is a reminder to Tongans about the faka'apa'apa (respect) and hierarchy within Va relationships especially that between a brother and sister. She goes on to say that the two vertical pillars are the brothers carrying their sister, fulfilling their fatongia (obligation) to care for the needs of their sister. According to the Tongan gender roles the females are ranked higher than the men in the community whereas the men have more political power. The mehikitanga (father's sister) controls the future of her brother's children, they are her faiteliha'anga. When she becomes a Mother or an Aunt she then takes on the role as Fahu/Mehikitanga while the brothers remain tu'a (lower in rank) as the fa'e tangata (Mother's brother) (Manu, p. 13).

Manu (2013) shares a deep and meaningful conversation with his grandmother, where she enables him to see the historical Ha'amonga 'a Maui site as a physical manifestation of the relational concept of vā, and, in doing so, brings forth the importance of respect and obligation.

In acknowledging these relationships and spaces, the research will draw connections from the vā as a portal and cultural lens to these Pacific historical 'tribal boundary areas'.

Standpoint epistemology gives an overview of my position and perspective with regard to this 
research. As a concept, indigenous epistemology focuses on the process through which knowledge is constructed and validated by a cultural group. In my research, the cultural group is composed of a pool of Pacific artists and theorists who influence thinking and behaviour of Pacific communities in Aotearoa/New Zealand. It was important to understand the diverse interpretations of va, and seek alternative meanings of vā to understand the different epistemologies arising from each standpoint. From the vā standpoint, indigenous ways of creating knowledge are part of understanding its full potential and diverse meanings, to justify its use within the research, and its significance to my cultural understanding. Drawing on the knowledge residing in this cultural group, and applying it to create space, has been vital to my project.

With regard to Pacific artists in Aotearoa, there have been a variety of references to the absence of space. This absence is confirmed by the artists all of whom embrace contemporary technologies and diasporic identities, and was discussed in Article One

In conculsion, one of the overarching themes in this research is the Sāmoan concept of vā. The vā has the potential to bridge a connection between identity and spatiality. It formulises a space of belonging and respect, and captures a glimpse of how we might better our awareness of the changing Pacific communities living in Aotearoa/New Zealand. 
Respect, although briefly discussed in terms of vā, is the vital interconnection in this article between the research undertaken and the practical element. It is my duty to pay respect and honour the sacredness of our Pacific knowledges, and to nurture the relationships and space.

\section{Fa'aSāmoa: The Sāmoan Way}

The fa'aSāmoa is our culture. It is the way we behave and act. It is respect, how we talk, righteous behaviors, royal conduct since we are descendents of kings, and servitude. These are just some of the things that encompass the fa'aSāmoa (Puaina, Aga, Pouesi, \& Hubbell, 2008, p. 25)

This article is located inside Sāmoan ways of knowing and being, and it draws upon collective thinking around indigenous knowledge. This section of the literature review examines what makes fa'aSāmoa significant to Pacific identity in the diaspora. Fa'aSāmoa is discussed because it sheds light on the complexity of customs and traditions in the Pacific.

Fa'aSāmoa refers to an all-pervasive system of governance and social organisation that affects most aspects of life in Sāmoa. It can simply be defined as 'the Sāmoan way of life', although it must be noted that the Sāmoan culture is diverse in terms of ideas, customs, myths and legends (Tagoilelagi, 1995). George Pratts (1893) defined fa'aSāmoa as 'an act according to Sāmoan customs' (p.131). In her book Tamaitai Samoa Their Stories, Peggy Fairbairn- 
Dunlop (1996) adds to this and defines fa'aSāmoa as in the manner of the Samoans; according to Samoan customs and tradition' (p.185).

The concept of fa'aSāmoa is essential to Sāmoan identity, and consists of a number of values and traditions, including:

'aiga (family)

matai (chiefly system)

lotu (Church \& Religion)

tautala Sāmoa (Sāmoan language)

gafa (genealogies)

fa'alavelave (ceremonial and other family obligations) (Howard, Shaw, Hoddell, Street, \& Wildblood, 2002, p. 25)

Fa'aSāmoa conceives of individuals as integral members of 'aiga, irrespective of where they currently reside. The development cycle of the 'aiga refers to its social, spiritual, physical, and economic improvement in parallel with the life cycles of the individuals within an 'aiga. Individuals are constantly reminded of their important contributions to the collective welfare. One develops one's 'aiga relationships through responsibilities that are maintained over time. Sāmoan society is highly stratified, and a person's status determines his or her roles, responsibilities and corresponding entitlements. This system is known as fa'amatai 
(Howard et al., 2002; Tagoilelagi, 1995; Tuagalu, 2009).

The fa'amatai is a chiefly hierarchical system whereby titled chiefs (matai) exercise responsibility and authority over extended family units. 'A matai title holder may be called an ali'I or tulafale, which become the trustee of the good name of the family. All ceremonial recognition of the status of his family rests upon him' (Tagoilelagi, 1995, p. 5).

Matai administer customary land, titles, and are responsible for upholding the family's good name and standing in the community. Therefore, fa'aSāmoa, in this sense, is a framework for action, based upon the social structure of the extended family (aiga) and the village (nu'u), with the authority of matai incorporated into it (Tagoilelagi, 1995, p. 5).

Christianity is part of the Sāmoan way of life, and it is located within fa'aSāmoa. Christianity was accepted by the Sāmoan people with negotiation and deliberation. Tagoilelagi (1995) asserts that missionaries had preached to middle-class individualism, and Protestantism became a major influence on the Sāmoan people.

Felix Keesing (1934) states that Sāmoans did not restructure their lives around Christianity; instead they took Christian practices and gave them a place inside fa'aSāmoa, making it part of their culture. Adding to his argument, Meleisea (1987) argues that despite the fact that some Sāmoan customs and 
practices contradicted the Christian ideals, Christianity was absorbed and 'Sāmoanized'. The Sāmoan people obtain their sense of unity from being a communal society. Because of this, the gathering of goods is established on a shared basis, unlike a pālagi middle-class society who save their goods (Crocombe, 1973; Tagoilelagi, 1995). Fa'asaulala Tagoilelagi's (1995) adds to this notion of a 'communal-based society':

The social organisation of a village is characteristic of the extended family living in close vicinity with each other, thus the sharing between each family is relatively easy. In most villages, there are committees specially designated for the women and single girls. A group called the aualuma consists of unmarried girls of the village, with a similar group for single men which is called the aumaga. The fa'amatai also exists within the village (p.6).

All aspects of fa'aSāmoa can be found in a typical Sāmoan village. The traditional and spiritual aspects of the villagers' lives are authorised and maintained by the matai and the supremacy of the village faifeau (pastor/s). Land is allocated to each áiga for their cultivation purposes and then what is produced is shared amongst the villagers. Tagoilelagi (1995) stresses that these general threads of reciprocity are woven within fa'aSāmoa. In a study conducted by health professionals Seumaninoa Puaina Daniel Aga, Daniel Pouesi and F. Allan Hubbell (2008), matai chiefs and faifeau 
were interviewed and voiced their perspectives and thoughts around fa'aSāmoa. Comments from the matai include:

\begin{abstract}
"Well as I said before, it all started from the top. In Sāmoa they have family, a clan of people that should be headed by a matai. The family is governed by the High Chief. He also governs the lands. He has the last saying. There are other chiefs of the family as well, but they are relegated to serving under the High Chief and assist in ensuring the wellbeing of the family under the care of the High Chief. One day, they too will become a High Chief, but only after servitude. If there is a funeral or a wedding, then you will see the Fa'aSämoa at its purest..." (cited in Puaina et al., 2008, p. 25).
\end{abstract}

Another matai asserted the importance of family to fa'aSāmoa, he comments:

"...We all know from the beginning of life that everything in the Fa'aSämoa begins with the family. In the family we raise and begin to mold the conduct of our children out in the world. It is the way we represent ourselves before others, within our families, villages, and in the world. Just like setting a table for dinner, the Fa'aSämoa teaches a child how to behave and act in a manner that is acceptable, like in setting the table, certain plates, utensils, and glasses are put forth, this is the Fa'aSāmoa (cited in Puaina et al., 2008, p. 26)

Comments from the faifeau include:

"The traditions and customs of our country, we can't do away with. We can't change them either. 
God created the world. He divided the world into different languages, like Sāmoan. He also gave each, traditions and customs to live by. These are the things that are important in Sāmoa; its traditions and customs. They're a way by which Sāmoan s relate to each other. It's relational. But what's most important is a life of worship. Sāmoan $s$ relate to each other through their traditions and customs. From these comes a life of respect. This life is centred on God. Everything is one because of God's name and purpose..." (cited in Puaina et al., 2008, p. 26)

"The Fa'aSāmoa is how one carries himself, it is something that is passed from generation to generation and will continue on till eternity. I also believe that this is one area that the new male generation is trying to change as well. But to me, I don't think it works that easily. You can't just barge in and change the Fa'aSämoa. This is one of the reasons that Sāmoan s are held in high esteem, because they have an identity that goes way back in history" (cited in Puaina et al., 2008, p. 26)

"The Fa'aSāmoa is one of the highest regards no matter where one travels. Sāmoan s are prideful and take great pride in who they are and where they come from. They never want to be put down by anyone, because they are descendents of royalty. There is no other culture around the world that compares to the Sāmoan culture" (cited in Puaina et al., 2008, p. 26)

These comments from the matai and faifeau show there is a general agreement among the group participants that fa'aSāmoa refers to the culture of the Sāmoan people. However, the men from the 
community discussed fa'aSāmoa in general terms, while the matai tended to stress the role of the chiefs in Sāmoan society, and the pastors stressed the importance of religion (Puaina et al., 2008). This highlights the importance of fa'aSāmoa in relation to an individual's role in a group/society. Over time, Western ways and migration has influenced the changes of fa'aSāmoa, although this also tells us that despite the effects of change, fa'aSāmoa still exists, even more so in the diaspora, because the diaspora hold onto it as crucial to their identity. Fa'aSāmoa in the diaspora has the capacity to change and re-new itself and still be regarded as tradition (Tagoilelagi, 1995).

Fa'aSāmoa practices in Sāmoa may differ from those in New Zealand, and it is important to realise that not every Sāmoan has the same understanding of the concept. It is my contention that the meanings and nuances of the vā fealoaloa'i, (relational space) though not lost, become muffled in translation, for there are marked differences between the village organisation in Sāmoa and the Church organisation in Aotearoa/New Zealand. That is, the Church does not have a set fa'alupega, a permanent geographical location, nor an unchanging population as the membership is transient. Tuagalu (2009) explains that the relational space taught in a Sāmoan village structure differs from that taught in the diasporic church organisations, and further outlines that the 
church has no 'permanent geographical location' (p. 121).

Given this outline of what makes fa'aSāmoa, the question can now be asked about the role it plays in the Sāmoan diaspora in relation to identity.

The change of social structure in Sāmoan church communities in New Zealand has provided a successful framework to sustain fa'aSāmoa. It is important to recognise these changes, and to understand that in some ways the term 'diaspora' no longer applies to this community. It is equally important to realise that change has occurred in the migrant communities (Yamamoto, 1996), adapting to different rules and set laws. Over the last 30 years, generations have been brought up as Sāmoan New Zealanders, each having been taught Sāmoan culture in different situations and contexts, with different understandings and meanings of the culture. Clifford (2007) maintains:

Later generations forced or drawn into towns or cities, have no realistic intention of actually living continuously in traditional places, then the connection to lost homelands comes closer to a diasporic relation, with its characteristic forms of longing and displaced performances of heritage ( $\mathrm{p}$. 202).

The paradoxical relationship between lost homelands and diaspora described by Clifford generates confusion. This is further exemplified in 
the relationship between customary label of one's identity and the circumstances in which a person is raised. In Melani Anae's (1997) focus group of New Zealand-born Sāmoans, she encapsulates the perplexity in the following verse:

I am a Sāmoan, but not a Sāmoan

To my 'aiga in Sāmoa, I am a palagi.

I am - A New Zealander, but not a New Zealander

To New Zealanders, I am a "bloody coconut" at worst, a "Pacific Islander" at best

I am - To my Sāmoan parents, their child (Anae, 1997, p. 128).

Anae's verse summarises the paradox of identity for many New Zealand-born Sāmoans, and New Zealand-born Pacific islanders in general. In Sāmoan communities, they are not 'Sāmoan enough', in the wider New Zealand community Sāmoans have been criticised as 'not New Zealanders', 'coconuts', or 'FOBs' (fresh off the boat). Anae investigates the issues of ethnic identity for New Zealand-born Sāmoans. She claims that secured identities can be reached by viewing the identity journey as a series of rites of passage enforced rituals that challenge one's right to be a New Zealander, and on the other hand, ones's right to be a Sāmoan. She goes on to argue that part of this challenge is the way in which New Zealand-born Samoans feel they are 'stereotyped by both papalagi and Sāmoan elders alike' (Anae, 1997, p. 128). 
These stereotypes are transmitted and perpetuated through negative images as well as in covert omissions of the positive characteristics of New Zealand-born and Island-born Sāmoans (Anae, 1997).

Linnekin and Poyer's (1990) suggestion that Pacific Islanders frame their identity based on context rather than heritage, is an argument that has been explored by scholars who are members of Pacific Island diaspora (Linnekin \& Poyer, 1990; McGrath, 2002; Tiatia, 1998; Tupuola, 2004). These authors have pointed out that different contexts require people to express different relationships to cultural knowledge (Gershon, 2007). In particular Tupuola (2004) has discussed how, in order to navigate social interactions effectively, the structuring of identity in different contexts requires a wide range of skills that do not always overlap. Operating as a Sāmoan in a bank branch is a somewhat different challenge than operating as a Sāmoan in a Sāmoan church. Anae (2001) notes that the paths by which people can acquire these social skills have been shifting in diaspora. Consequently, the types of knowledge one must exhibit in order to claim an identity is, effectively, constantly changing.

In particular, language skills become a focus through which people explore such challenges. Anae proposes that in the diaspora, migrants are continually struggling to answer the question: To what degree can someone who does not speak 
Sāmoan be a Sāmoan?' She advocates that New Zealand-raised Sāmoans frequently have uneasy relationships with their Sāmoan identity, largely because of their varying degrees of comfort with the Sāmoan language: 'Inability to speak Sāmoan, or tautala fa'asāmoa, became the prime source of Sāmoan identity confusion'(Anae, 2001, p. 110). Anae argues that although her interlocutors might not be able to speak Sāmoan fluently, or at all, they were quite capable of understanding Sāmoan that is, they were fluent listeners, not speakers (Gershon, 2007).

Tiatia (1998), in her book Caught between Cultures, displays a diagram which highlights some binaries between the Western structure and the traditional structure in the diaspora.

\begin{tabular}{|l|l|}
\hline $\begin{array}{l}\text { Sāmoan / Tongan/ Niuean } \\
\text { Culture }\end{array}$ & Western System \\
\hline Communalism & Individualism \\
\hline $\begin{array}{l}\text { Unquestioned obedience } \\
\text { and respect for seniority }\end{array}$ & critique \\
\hline $\begin{array}{l}\text { Understand and speak the } \\
\text { mother tongue }\end{array}$ & $\begin{array}{l}\text { Speak the English } \\
\text { language }\end{array}$ \\
\hline $\begin{array}{l}\text { Church and extended family } \\
\text { obligations first }\end{array}$ & $\begin{array}{l}\text { Education/ work } \\
\text { first }\end{array}$ \\
\hline $\begin{array}{l}\text { Fa'a Sämoa / Anga faka } \\
\text { Tonga/ Faka Niue }\end{array}$ & Fa'a palagi \\
\hline
\end{tabular}




\begin{tabular}{|l|l|}
\hline 'you are palagi' & $\begin{array}{l}\text { you are a Pacific } \\
\text { Islander' }\end{array}$ \\
\hline 'Don't ask, just do it' & $\begin{array}{l}\text { 'Ask before you go } \\
\text { ahead' }\end{array}$ \\
\hline
\end{tabular}

(Tiatia, 1998, p. 71)

Tiatia's discussion focuseds on Pacific youth raised in both the Western structure and the traditional household structure, and the difficulties between the two ways of living. She conducted interviews and recorded youth recounting their upbringing in both systems as being 'caught between cultures'. All of the participants that Tiatia interviewed had shared similarities in their experiences. She recorded ideas of tension, confusion, and cultural cringe/rejection. These views may leave some with a secure selfidentity, but others in a state of confusion. Many young diasporic Pacific people talk about having 'time out' as a reaction to the difficulty of identity. This usually involves leaving the church and rejecting parental authority (Anae, 1997; Tagoilelagi, 1995; Tiatia, 1998).

There is an underlying theme in the literature, specifically in Tiatia's Caught between Cultures, of the space between, the vā. These youth feel as if they are constantly negotiating and renegotiating the space between two cultures (Whimp, 2009). Building on the discussion of recent Pacific art practice in Article One (Position of Research), this 
article has considered theoretical knowledge impacting on the design and realisation of the vā.

This discussion on fa'aSāmoa has been useful in affirming my own cultural journey as a blended Sāmoan, Fijian Indian Spatial Designer, who respectfully acknowledges the cultural sensitivity of the Pacific diasporic communities, and expands upon the ideas of traditional knowledge. Having now outlined theories that impact on the potential of vā, it is useful to state my own standpoint in relation to the literature review.

\section{Standpoint epistemologies}

'Epistemologically, vā is encoded with respect, service, and hospitality in maintaining and retaining 'aiga status and a socially well-located family' (Lilomaiava-Doktor, 2009, p. 14).

In the article 'How We Know: Kwara'ae Rural Villagers Doing Indigenous Epistemology', David Welchman Gegeo and Karen Ann Watson-Gegeo (2001) revise theories of knowledge, including the nature, sources, frameworks, and limits of knowledge. They state that 'epistemological agents are communities rather than individuals' (Gegeo \& Watson-Gegeo, 2001, p. 58). In other words, knowledge is created by communities, rather than collections of individuals independently knowing, and 'such communities are epistemologically prior to individuals who know' (Nelson 1993, p. 124). 
For Gegeo and Watson-Gegeo (2001) the concept of indigenous epistemology distinguishes between accounts of other people's knowledge, on the one hand, and cultural insiders' ways of theorising knowledge, on the other. In my research, indigenous epistemology means, specifically, the ways of thinking and creating, reformulating, and theorising about knowledge that are activated by Sāmoan communities away from Sāmoa - through traditional discourses and media of communication. As a concept, indigenous epistemology focuses on the process through which knowledge is constructed and validated by a cultural group. In my research, the cultural group is composed of a pool of Pacific artists and theorists who influence the thinking and behaviour of Pacific communities in Aotearoa. It was important to understand the diverse interpretations, and seek alternative meanings of vā (i.e absence of space) to understand the different epistemologies arising from each standpoint. From the vā standpoint, indigenous ways of creating knowledge are part of understanding its full potential and diverse meanings, to justify its use within the research, and its significance to my cultural understanding. Drawing on the knowledge residing in this cultural group, and applying it to create space, has been vital to my project. 
Through these interpretations, I have come to conclude that this space of vā, for me, is a space of relationships that have been built around me and with each other. I was raised in a Sāmoan church community as a Christian to speak Sāmoan and learn the Sāmoan way, fa'aSāmoa. Being half Sāmoan and also living in a Western society, fa'aSāmoa was not really clear for me at times, and I felt a sense of loss and a lack of belonging. Having been educated in a Western society, it was hard for me to distinguish the cross-cultural boundaries, and at times understand the culture in my own church community in regards to my identity. I want to make it clear that in no way am I criticising church values; I am simply trying to identify the key aspects of what made my experience different from other full Samoan youth members, and discover if others, like myself, felt the same way. Like Anae (1997) I tried to encapsulate my perplexity in the following verse:

- I am half Sāmoan half Fijian Indian. Two different cultures, one identity.

- I was born, raised and educated in New Zealand.

- I am a member of the congregational church of Sāmoa; learning Sāmoan Christian values and fa'aSāmoa, the Sāmoan way.

I felt to some degree like an outsider in my own church. It took me longer than other full Sāmoan 
youth to learn and understand the Sāmoan way because I struggled with the language. Gagana Sāmoa is the essence of fa'aSāmoa because both interconnect and feed one another; they too can be described as lalaga, a weaving of balance from two entities. The language was a barrier, and even with translations, Sāmoan traditional customs required another level of expertise, and how was I to understand? Surely there must have been others in my position struggling to adapt to the customs, traditions and language. I turned to what I knew best and educated myself through articles, books, the internet and of course my family, in order to understand my culture and the importance of sustaining items such as 'ie tōga in our culture. This form of learning made me think about other means of teaching and learning fa'aSāmoa, and prompted the queston: 'How else could we as Sāmoan diaspora pass on our values and customs to our youth if they too feel disconnected from their cultural identity?'

\section{Pacific Peoples in Aotearoa/New Zealand}

This section examines the history of Pacific diasporic communities, and how they sustain their cultural values, expressed through their identity. Knowledge relating to diaspora is relevant to this research as it not only addresses the key question in this research, but also gives insight into the lives of the participants that I interviewed for this article. 


\title{
Diaspora
}

Many cultural communities move from one homeland to another site of settlement, either for economic opportunity or political refuge (Clifford, 1997). In doing so, they reconstitute their cultural and communication practices considerably to reflect upon their migration experiences (Drzewiecka \& Halualani, 2002). Also, upon moving to new places, cultural groups adapt, incorporate, and modernise (Westernise) to fit into new host countries, sometimes casting aside their traditional cultural practices.

\begin{abstract}
As is often described, 'diaspora' is both a spatial and a biological term, its original Greek meaning defines 'diaspora to sow, scatter, distribute or disperse. It communicates the movement of people from a centre outwards, of their dispersal from the place of origin into new territories... It is, by implication, 'a travelling term', one that carries the merged concepts of 'root' and 'route'. It has become a popular term amongst academics reflecting a move from a scholarly of community, culture, nation, centre and continuity to strategies of movement and discontinuity, circulation and contact zone (Jackson, Crang, \& Dwyer, 2004, p. 2).
\end{abstract}

Global movements and journeys, are not the sole focus of attention for geographers of diaspora and the other scholars who focus on space and circulation. As Jackson et al. (2004) argue: 
Different diasporas are characterized by different geographies that go beyond simple oppositions between the national and the transnational, the rooted and the routed, the territorial and the deterritorialized. Diaspora is not only an inherently spatial term. Its particular historical forms evidence particular and distinctive spatialities. (p. 2)

Every diaspora - whether recent or long-standing, caused by exile or movement for trade, multi-sited or settled in a single place - has its distinctive spatiality informed by actual journeys past and present, the particular forms and distribution of its settlements, its demography, the characteristic circulations of its members, goods, culture and religion, its local inflections (social, linguistic, cultural), and its distinctive imagined, historical and present geography (Jackson et al., 2004).

\section{Pacific Migration}

The first thing one notices when one looks at the history of Pacific Islander migration is that this has always been a diasporic movement (Spickard, Rondilla, \& Hippolite Wright, 2002, p. 15). 


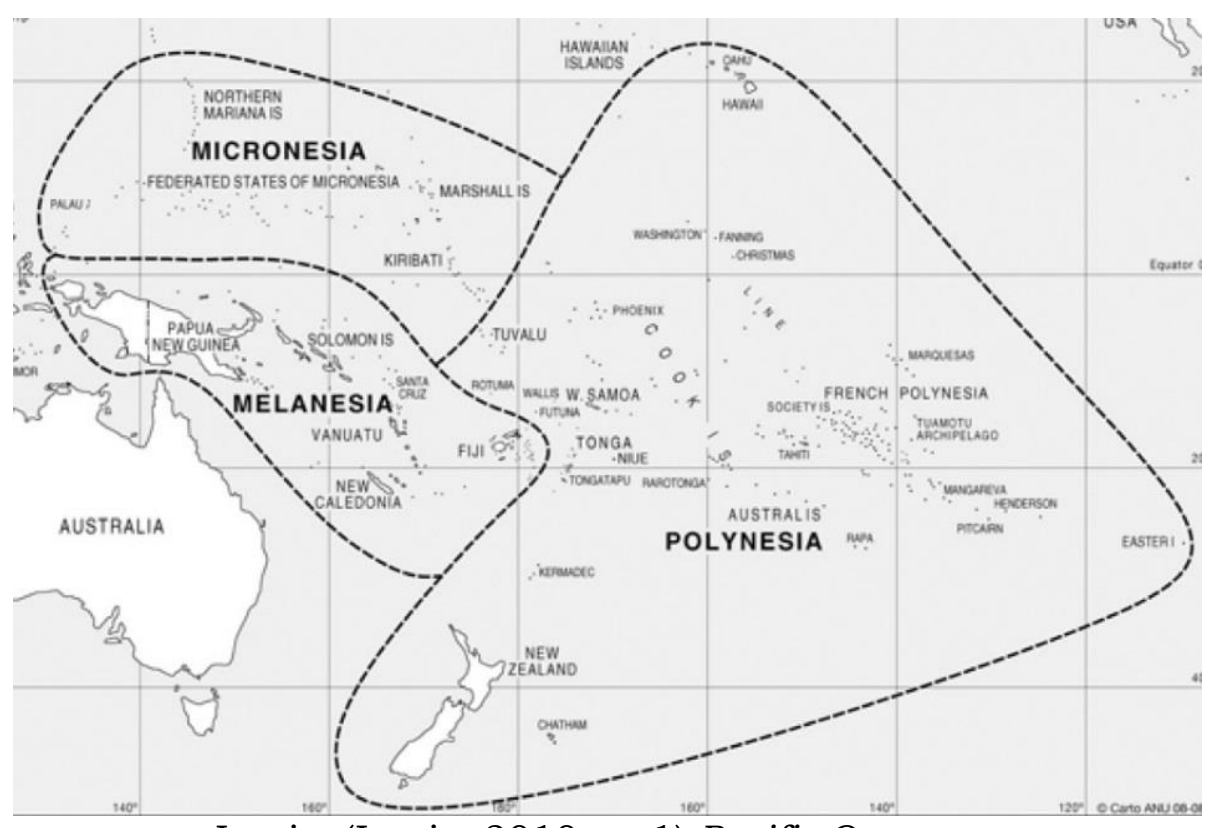

Lewis. (Lewis, 2010, p. 1) Pacific Ocean,

The Pacific diaspora is thousands of years old. For a very long time, people have been moving around the Pacific Ocean. In modern times, analysts have divided the Pacific Ocean into three groups of islands and peoples. Melanesia is the name given to a wide-ranging band of islands, many of them densely populated, extending from Fiji, just west of the International Date Line, to New Guinea at the doorstep of Southeast Asia. Melanesia is the home to hundreds of discrete societies and language groups. Micronesia is another band of 
islands north of Melanesia. Micronesia consists of thousands of tiny islands spread out by the wide ocean, and is culturally-similar to Melanesia. Polynesia is the third band of islands. It is a large arrowhead-shaped region that starts from Hawai'i in the north to Aotearoa/New Zealand in the south, and from Tuvalu in the west to Easter Island in the east. The peoples of Polynesia speak closely-related, often mutually-intelligible languages despite the vast stretches of ocean that separate them (Spickard et al., 2002). Many Pacific Island peoples have migrated to New Zealand, and the majority of these peoples are Polynesians.

A great number of Pacific Island people have formed diasporic communities around the world, often being grouped together as islanders, P.Is, Pacifika and Pacific people (Macpherson, 2004; Morton, 1998; Perrott, 2007; Teaiwa \& Mallon, 2005). They have formed active communities with their own individual identities and, in some cases, with their own media (Papoutsaki \& Strickland, 2008). Aotearoa/New Zealand hosts the largest Pacific Island diaspora community in the world.

There are growing references to Pacific Island communities living overseas as Pacific diasporas. Helen Morton's (1998) research examines diasporic Tongan youth in Australia and their effort to create their own culture. Her research argues that their cultural identity is created in conjunction with their 
roles within their family, obligations to their church, and how they respond to the host culture.

In a article entitled 'New Zealand's Pacific Advantage', McCarthy (2005) discusses the importance of Pacific diasporas. He references his encounter with the Chief Executive at the Ministry of Pacific Islands Affairs, who argues that people from New Zealand's many Pacific diaspora communities can and do play significant individual and collective roles in helping to secure a peaceful Pacific. In their book 'Pacific Diaspora: Island Peoples in the United States and Across the Pacific', Spickard et al. (2002) discover the, 'transnational or diasporic model' in examining the Pacific communities living overseas, which highlights the on-going links with their people at home or overseas (p. 7). They also explore the 'pan-ethnicity model', which is more distinctive among second and third generation Pacific Island migrants, who are increasingly seeing themselves as Pacific people with one identity (Papoutsaki \& Strickland, 2008, p. 7).

Referring to this disputed identity, Popoutsaki and Strickland refer to Perrott (2007) in his article, 'Pacifika: Identity of Ilusion?'. Perrot captures the dilemma New Zealand-born Pacific youth have with understanding their own identity. The article appeared as a cover story in the weekend magazine of a mainstream Aotearoa/New Zealand newspaper, and indicated that Pacific peoples, who are one of 
the most visible minority groups in Aotearoa/New Zealand, are becoming an important identity group that merit the attention of mainstream mass media. Pacific Island people are visible in Aotearoa/New Zealand society not only because of their presence in numbers but also through their involvement in national sports and the cultural life of the country (Papoutsaki \& Strickland, 2008).

While there is a significant body of work on the Pacific Islands and Pacific Island peoples in Aotearoa/New Zealand, Popoutsaki and Strickland (2008) point out the noticeable lack of research on how these communities communicate with each other, with their homes, and with their host country environments; how they are represented in the mainstream mass media, and what their information needs are and how they satisfy them. The most thorough body of work in the wider area of immigrants in Aotearoa/New Zealand comes from Spoonley's $(2001,2004)$ migration research, which gives a researcher on Pacific diasporas and media a respectable starting point.

Pacific communities in Aotearoa/New Zealand could be what Popoutsaki and Strickland (2008) describe as trade diaspora, at least in the early migration stage. An increase in the demand for labour created rapid growth in the size of the Pacific migrant population, and this growth has continued since the 1960 s. It is one of the fastest growing populations in the country (Logan, May-June, 2006). The Pacific 
descent population is expected to grow by 181 per cent by 2051, from 232,000 to 599,000 , making up 18 per cent of Aotearoa/New Zealand's population' (Cook, Didham, \& Khawaja, 2001, p. 62). Some Islands have seen more than half of their population migrating to Aotearoa/New Zealand and elsewhere, and in some cases, 70 per cent of their diaspora members have been born in Aotearoa/New Zealand (Macpherson, 2004; McCarthy, 2005; Teaiwa \& Mallon, 2005).

Macpherson detects that the gradual replacement of the term Pacific Islanders with the terms Pacific people in official and popular discourse is an acknowledgment of the fact that most people of Pacific descent are no longer from the 'traditional island homelands, and that their commonalities derive from culture rather than place of birth' (Macpherson, 2004, p. 139). This shows a need to acknowledge that these communities will start playing a considerable social, economic and political role in New Zealand society (Papoutsaki \& Strickland, 2008). New Zealand-born Pacific people are becoming more important in today's society, and their social mobility has made them increasingly visible in roles which challenge earlier social stereotypes held of them by Pakeha/Europeans' (Macpherson, 2004, p. 140).

Additionally, for Pacific peoples, one needs to overcome the general tendency to look at them as one single group (Macpherson, 2004). It also shapes 
how the broader society of people and media understand these communities. At the same time, Popoutsaki and Strickland (2008) point to Macpherson's research that shows New Zealandborn Pacific children, like most children of immigrants, differ from their island-born parents in various ways. This is evident in smaller island groups where they are losing fluency in their mother tongues (Collins, May 30, 2008). Cultural preservation is more advanced among the larger communities, such as the Sāmoans, who, due to their size, can provide more cultural reinforcement (Papoutsaki \& Strickland, 2008).

The present argument is whether we now have new ethnic identities, which focus on shared Polynesian descent, pan-Polynesian or 'nesian' identities e.g. 'New Zealand borns', 'P.I.'s' , 'Polys', or 'Pasifikans' (Teaiwa \& Mallon, 2005, p. 210). These identities have been acknowledged by Teaiwa and Mallon, and they are recognised mainly through the popular culture that has emerged around a vibrant new music and pop culture.

\section{Pacific Diaspora in New Zealand}

Diaspora implies that a sense of particularity and ethnic belonging is not only attached to the experience of migration, but it might have an ongoing importance for younger generations who have not experienced migration processes ... diaspora implies that particular cultures survive, transform and remain relevant even when members of an 
ethnic community have not lived in the original Homeland (Myria Georgiou, 2007, p. 1).

The circumstances of Pacific peoples living in Aotearoa/New Zealand are complex. Yamamoto (1996) states: Diaspora in the past meant leaving the homeland forever. It accompanied the feeling of loss, losing one's native idioms, family ties, and the attachment to one's roots, but this is not always the case for the New Zealand Pacific communities. From the 1950s, Pacific Island people migrated to New Zealand in large numbers (Anae, 2000). New Zealand's industry and the service sector expanded over the next 30 years. Many Sāmoan and Tongan communities moved to New Zealand to seek greater opportunities and a better education for their children. Within this span of 30 years, diasporic Pacific Islanders (predominately Polynesians) coped, in part, by becoming part of church communities. In New Zealand cities, Pacific Island churches increased in numbers. They subsequently took on the role of villages to provide a platform for what Sāmoans would call fa'asinomaga (identity).

However, when viewing diaspora from the Pacific, Gershon (2007) describes how analysts of transnational movements tend to see diaspora as disruptive to families. The concerns are with ways in which travel and distance force people to reconfigure their families in response to the need to migrate (Gershon, 2007). Furthermore, Portes and 
Rumbaut (2001), argue that second-generation immigrants struggle with adaptation as they respond to parental and societal demands, with parents standing for the homeland culture. Whereas others, such as Park (1997) and Brettell (2003), discuss the dynamics underlying changes in gender relations among diasporic migrants. The authors highlight ruptures and reconstructions, often describing diasporas as obstacles to be overcome by families.

However, my research among diaspora participants looks specifically at families and their connections in terms of how they sustain their cultural identity, and what makes them visible within the community. Without families, and the transmission of knowledge among families, how would diasporas survive? How will concepts and differences between cultural or ethnic identity be interpreted in diaspora? By pointing out that families are the culturally-specific, integral units that form diasporas, I am building on Epeli Hau'ofa's (1994) insight that to understand the Pacific, one is better served understanding people's daily experiences of interconnected webs of exchanges and kinship than by focusing on the disconnections and isolations integral to a Western colonial perspective (Hau'ofa, 1994). Ethnographers of the Pacific have long known that the Pacific is not just a sea of islands, but also a sea of families. Culturally sustainable diaspora exists because of the culturally-specific 
ways through which families circulate knowledge and resources. Families and diasporas are interconnected, they rely upon one another, to such a degree that diasporas cannot exist across generations without families sustaining them (Spoonley, 2000). This is supported by Gershon, who states:

By reconceptualising the migrants as members of family networks, scholars opened the door to seeing the people they studied as more than simply individuals seeking other lives when leaving one country for another. Migrants were instead seen as part of larger diasporas in which knowledge and resources circulated through people in multiple directions - to their local friends and relatives as well as to their families back home (Gershon, 2007, pp. 477-478).

In Pacific Island diaspora literature, questions of identity often also involve questions of how knowledge circulates, and how these patterns of circulation might have changed across distances I assert that when people are reflecting openly on their identity, they are also expressing how they personally experience and respond to the ways knowledge circulation connects them to various communities. When a Sāmoan woman talks about how she no longer participates in Sāmoan community functions in Seattle because of the gossip she encounters (McGrath 2002, p. 310-311), she is reflecting on how she manages the circulation 
of knowledge about her and through her. When a New Zealand-raised Sāmoan woman insists that she is Sāmoan despite the fact that she does not speak Sāmoan fluently (Anae, 2001), she is commenting on more than identity labels and their values; She is also addressing the ways patterns of language acquisition, such as those Elinor Ochs delineated (1988), have shifted as people move away from Sāmoa. In short, just as exchange in diaspora becomes a vehicle for addressing scale-making, so too identity becomes a vehicle for reflecting on changing patterns of knowledge circulation.

Scholars of Pacific Island diaspora have discussed two ways that Pacific Islanders use identity to comment on how they are involved in knowledge circulation. First, ethnographers have addressed how patterns of knowledge acquisition have impacted peoples claims and understandings of identity. Second, they have examined the ways people respond to the fact that being in a community is also about knowing and being (Gershon, 2012). Anae (year) pointed out, that the paths by which people can acquire these skills have been shifting in diaspora. As a consequence, what it means to have an identity-that is, the types of knowledges one must exhibit in order to claim an identity effectively-are also constantly changing (Anae, 2001, 2002). 
What is also changing is the use of the term diaspora. There is a weakness to the use of the word diaspora for Pacific Islanders living in Aotearoa/New Zealand, and it exists when referring to the second generation of the diaspora. The vast bulk of the Pacific Island population that lives outside the Pacific in places like Australia, has done so for only about a generation and a half. As the next (second and third) generations come of age, it is entirely possible that the notion of island-based diaspora will not serve as well as it did when compared to the first generation of migrants (Spickard et al., 2002). A new identity seems to be on the verge of being formed in Aotearoa/New Zealand: not Tongan, not Sāmoan, not Hawaiian, not Māori, not Cook Island, but a blend of these identities. For at least two generations, people whose parents were Tongan immigrants may see themselves as two things at once: Tongans and Tongan New Zealanders. But as time goes on, that second, pan-ethnic identity is likely to become more important (Spickard et al., 2002). Macpherson and Bedford (1999) see such a pan-ethnic formation happening amongst the children of Pacific Island migrants in Aotearoa/New Zealand. Their paper 'The Structured Roots of Transformation of Pacific Identity in Aotearoa' refers to:

The emergence of "Pacific" or "PI" world-views and practices. Thus, for instance, to organise a Pacific 
cricket tournament a group of people from different sub-groups came together to form a common body of rules for playing "Pacific cricket". The result is a game which is not Sāmoan, or Cook Island but "Pacific". "PI" identities are expressed in new syncretic musics as for instance in the music of Te Vaka, in performance art as for instance in the work of Pacific Underground, in patois and language registers which mark a commitment to belonging, in new clothing and building design (p. 2)

Will such blending happen among Pacific Islanders in the generations to come? Do we as a migrant Pacific community acknowledge the blending of not only our cultures, but also our values, ethnicities and beliefs? Pacific diaspora is a critical concept surrounding the framework of this research as in 'How do we as the next generation view our blended cultural identities as Pacific diaspora?' Furthermore, how do my skills as a Spatial Designer help explore new methods of valuing blended identity in Aotearoa/New Zealand?

\section{Paint by numbers}

In this section, I will explore the literature surrounding the growing diversity in Aotearoa/New Zealand, supported by statistics compiled and collected from Statistics New Zealand.I have chosen to use data sourced from Statistics New Zealand, because of the reliability and credibility of Statistics New Zealand. A century of censuses show long-term trends. Long-term trends bring together a range of 
indicators from censuses over the years, and show how New Zealand's population and dwellings have changed over time. This rich information helps people decide where to locate a business, what products to sell, where we need roads, schools and hospitals as well as measuring environmental progress, quality of life and how family wellbeing. Statistics are used by government, local councils, Māori and businesses to help make decisions so that New Zealand's economy, people and communities can thrive (Statistics New Zealand, 2015).

In 1956, almost 93 percent of the New Zealand population identified as European, 6.3 percent as Maori and 0.4 percent as Pacific Islander. At this time, New Zealand was predominantly seen as a Pālagi country. In 2013, the demographic breakdown had become 74.0 percent European/Pakeha, 14.9 percent Maori and 7.4 percent Pacific peoples, with 11.8 percent Asian and 1.2 percent from the Middle East (Statistics New Zealand, 2014).

The Pacific peoples ethnic group was the fourthlargest major ethnic group in 2013, behind the European, Māori, and Asian ethnic groups. The Pacific peoples ethnic group also had the highest proportion of children (aged 0-14 years), at 35.7 percent. Māori were the next highest proportion at 33.8 percent. The city of Auckland is often described as the 'Polynesian capital of the world' with almost 
two-thirds of Pacific peoples (65.9 percent or 194,958 people) living in the Auckland region.

Table 1 shows the Pacific Islands of Niue, Tokelau and the Cook Islands having more than two-thirds of their population living in New Zealand. Maori and Pacific media have expanded and transformed along with the demographic changes and played a critical role in self-determination. Ethnic media is in its infancy but also rapidly evolving (Robie, 2009).

Table 1: Pacific Island population for selected Countries

\begin{tabular}{|l|l|l|l|l|}
\hline COUNTRY & $\begin{array}{l}\text { NO. IN } \\
\text { HOME } \\
\text { COUNTRY(1) }\end{array}$ & $\begin{array}{l}\text { NO. IN } \\
\text { NZ(2) }\end{array}$ & $\begin{array}{l}\text { IN } \\
\text { HOME } \\
\text { COUNTRY }\end{array}$ & $\begin{array}{l}\text { \% IN } \\
\text { NZ }\end{array}$ \\
\hline FIJI & 867,000 & $25,374(3)$ & 99 & 1 \\
\hline SĀMOA & 187,820 & 144,138 & 57 & 43 \\
\hline TONGA & 103,252 & 60,333 & 63 & 37 \\
\hline $\begin{array}{l}\text { COOK } \\
\text { ISLANDS }\end{array}$ & 19,100 & $61,839(4)$ & 24 & 76 \\
\hline TUVALU & 10,640 & 3,537 & 75 & 25 \\
\hline TOKELAU & 1,411 & 7,176 & 16 & 84 \\
\hline NIUE & 1,470 & 23,883 & 6 & 94 \\
\hline
\end{tabular}

Source:

(1)

https://en.wikipedia.org/wiki/List_of_countries_and_depende ncies_by_population 
(2) 2013 New Zealand Census of Population and Dwellings

(3) Includes 10,929 from the Fijian Indian ethnic group

(4) Includes 792 from the Rarotongan ethnic group

Religious association has also changed significantly in recent years. Since colonization, New Zealand has traditionally been a predominantly Christian country. This defining characteristic has eroded quite suddenly since the turn of the century. In the 2006 New Zealand Census, just over 2 million people, or 55.6 percent of those answering a religious affiliation question, identified with a Christian religion (including Maoori Christian, such as the Rātana faith). In the previous 2001 Census, 60.6 percent of people surveyed affiliated with a Christian religion. In contrast, between 2001 and 2006 there was an increase of people affiliated with non-Christian religions (Robie, 2009).

Understanding the data in Table 2, Graph 1 and Graph 2.

In the face of public pressure, Statistics New Zealand has permitted people to select more than one ethnicity in the census, and children can now also be assigned more than one ethnic group at birth (Statistics New Zealand, 2015). Statistics New Zealand (2015) define ethnicity/ethnic group in the following way; 
Ethnicity is the ethnic group or groups a person identifies with or has a sense of belonging to. It is a measure of cultural affiliation (in contrast to race, ancestry, nationality, or citizenship). Ethnicity is self-perceived and a person can belong to more than one ethnic group.

An ethnic group is made up of people who have some or all of the following characteristics:

- a common proper name

- one or more elements of common culture that need not be specified, but may include religion, customs, or language

- a unique community of interests, feelings, and actions

- a shared sense of common origins or ancestry

- a common geographic origin (p. 1)

The following data has been drawn from the New Zealand Census of Population and Dwellings, 19862013. It represents Pacific and Māori multiple ethnic responses over time from the Census. From the 1986 Census to the 2013 Census the classification of ethnicity went through significant changes. The 2013 Census and 2006 Census are fully comparable, the 2001 Census somewhat less so. In these three series, respondents were able to select 
up to six ethnic responses. In the 1996 Census the ethnicity question is more akin to ancestry. In the 1996, 1991 and 1986 Censuses, respondents were able to choose up to three ethnic responses. Table 2 shows Census usually-resident population counts from 1986 to 2013 for selected ethnic groupings.

Table 2: Selected ethnic counts from New Zealand Censuses 1986-2013

\begin{tabular}{|l|l|l|l|l|l|}
\hline Census & $\begin{array}{l}\text { Multiple } \\
\text { Pacific(1) }^{(1)}\end{array}$ & Pacific(2) $^{\text {Māori }}$ & $\begin{array}{l}\text { Māori(4) } \\
\text { and } \\
\text { Pacific(3) }\end{array}$ & $\begin{array}{l}\text { Total } \\
\text { stated(5) }\end{array}$ \\
\hline 1986 & 4,599 & 130,122 & 10,887 & 404,778 & $3,226,722$ \\
\hline 1991 & 5,877 & 167,073 & 14,136 & 434,847 & $3,345,813$ \\
\hline 1996 & 13,743 & 202,236 & 29,055 & 523,371 & $3,466,587$ \\
\hline 2001 & 15,549 & 231,801 & 31,548 & 526,281 & $3,586,734$ \\
\hline 2006 & 19,890 & 265,974 & 39,681 & 565,329 & $3,860,163$ \\
\hline 2013 & 25,356 & 295,941 & 49,125 & 598,602 & $4,011,402$ \\
\hline
\end{tabular}

Source: Statistics New Zealand Customised Census data

(1) Multiple Pacific: At least two ethnic responses fall into current Pacific ethnic group.

(2) Pacific: At least one ethnic response falls into current Pacific ethnic group.

(3) Māori and Pacific: One ethnic response is Māori ethnic group, and at least one other ethnic response falls into current Pacific ethnic group

(4) Māori: One ethnic response is Māori ethnic group, with or without other ethnic groups.

(5) Total stated: At least one ethnic response is coded. 


\section{Graph 1: Pacific ethnic group and Māori ethnic group counts Censuses 1986-2013}

\section{PACIFIC(1) \& MĀORI(2) \\ 틀 1986 를 1991 틀 1996 르 2001 를 2006 틀 2013}

700,000

600,000

500,000

400,000

300,000

200,000

100,000

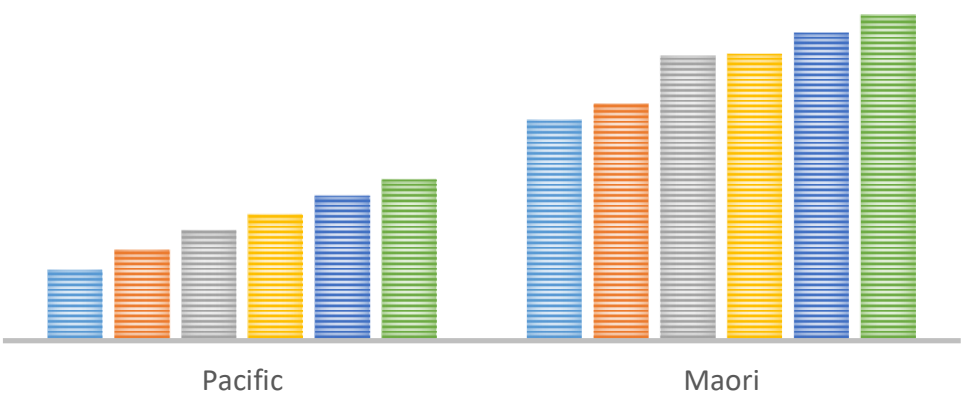

Source: Statistics New Zealand Customised Census data (1) Pacific: At least one ethnic response falls into current Pacific ethnic group.

(2) Maori: One ethnic response is Maori ethnic group, with or without other ethnic groups. 


\section{Graph 2: Pacific with multiple ethnic group and Pacific with Māori ethnic group counts Censuses 1986-2013}

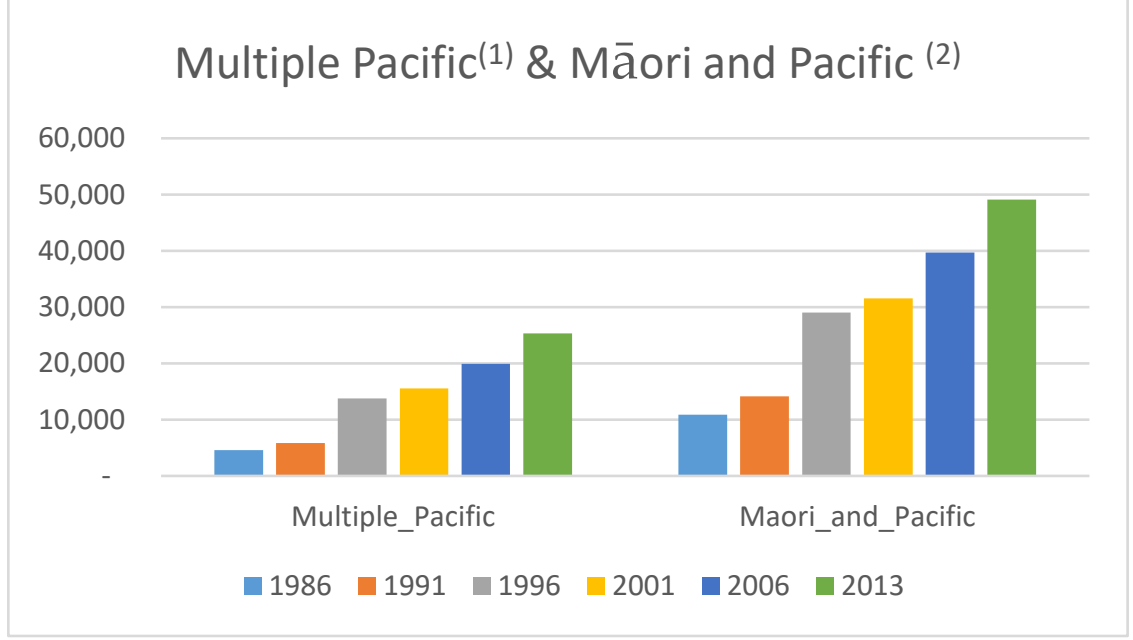

Source: Statistics New Zealand Customised Census data

(1) Multiple Pacific: At least two ethnic responses fall into current Pacific ethnic group.

(2) Māori and Pacific: One ethnic response is Māori ethnic group, and at least one other ethnic response falls into current Pacific ethnic group

Over the last three decades the Pacific population has increased by $127 \%$ from 130,122 in 1986 to 295,941 in 2013 (Graph 1). In the same period, Pacific peoples, who identified with at least one Pacific ethnicity and any other another ethnicity, increased by $451 \%$ from 4,599 in 1986 to 25,356 in 2013 (Graph 2). This extraordinary growth in multiple ethnicities particularly between Pacific with Māori does not appear to slow. The New 
Zealand 2006 Census showed that 10 percent of the population reported belonging to at least two ethnic groups, rising to 20 percent amongst children aged under 15 years (Statistics New Zealand, 2007). More recently, the 2013 Census revealed more than 50 percent of the Māori population (53.5 percent or 320,406 people) identified with two or more ethnic groups, compared with 46.5 percent who identified with Māori only. Māori was the only major ethnic group in which people were more likely to identify with two or more major ethnic groups rather than just one (Statistics New Zealand, 2007).

More specific to the Youth Census (2014), the survey generally outlined that amongst youth in New Zealand, about two-thirds of Māori responses were recorded as multi-ethnic, and a relatively high percentage of Pacific and 'other' ethnic groups were recorded as part of a complex ethnic repertoire (relating to at least 3 ethnic groups, if not more). Younger people identify with more ethnic groups than older people. Children (0-14 years) were more likely to belong to more than one ethnic group than people aged 65 years and over.

This difference has increased since the 2006 Census. Overall, the proportion of the population identifying with more than one ethnic group increased across recent censuses. The proportions of people identifying with more than one ethnic group were: 
- 11.2 percent in 2013

- 10.4 percent in 2006

- 9.0 percent in 2001 (Statistics New Zealand, 2014, p. 1).

Looking further back, the 2001 Census indicated that 10 percent of the total New Zealand population comprised ethnic migrant communities other than Maori and Pasifika. Projected demographics by Statistics New Zealand (2007) indicate that the country's Asian population could almost double by 2026. The Pacific and Maori populations will also experience increases of 59 and 29 percent respectively. A strategic approach to multicultural diversity is increasingly apparent and essential.

Since diasporas tend to be on the borders of two cultures and two societies, which are never completely interpenetrated and fused (Park, 1997), they often create devices of coping with contradictory needs to integrate in the latter cultural norms, and to maintain aspects of their distinct identity and contact with the former cultural norms (Tsagarousianou, 2002). In this process of coping and transformation, the concept of hybridity is useful for better understanding Pacific Island diasporic minorities. They are:

characterised by internal diversity, especially within generations ... how diasporic cultures are not homogenous, harmonious or singular 
expressions of community consensus ... and how they actually involve negotiations and conflicts within and outside the group (M Georgiou, 2001, p.

1)

The concept of hybridity implies many points of departure and multiple destinations, and it suggests instabilities and inequalities, not only in the meeting of two different cultures or populations, but within any of those cultures, groups and communities, as much as in-between (Papoutsaki \& Strickland, 2008).

\section{Hybrid Identity}

Hybrid identity is discussed in relation to an individual who identifies with more than one culture. Bolatagici (2004) names hybridity as:

the fundamental concept of a location that moves beyond reduced definitions such as black and white and opens the possibility to consider the biracial: not as half of two things, but a whole 'new' entity that is not reducible to its components (p. 78).

Her work has roots in the work of Bhabha (1994) who names the hybrid cultural experience as being the third, not a blending of the two originals but a third that is created by the action of blending. The third space gives opportunity for individuals to move from the binary position of Maori or Pakeha', with the positioning of each in an essentialised culture, to a place of continuum and flexibility (Grennell, 
2014; Keddell, 2006; Moeke-Maxwell, 2005). This third space I like to conceptualise as being the vā. It is also helpful to note that there are possibilities that come by moving to the hybrid cultural identification. Belonging in both, although being something that is neither, multiplies opportunities and experience. Moeke-Maxwell (2005) expands on this:

The concept of hybridity is liberating because it opens up a space to think about the way New Zealand colonial culture creates unequal subjects. The concept is emancipatory in that its existence (construction and performance) liberates the subject from a sense of unbelonging, dislocation and alienation, and a partial participation and location within the culture(s) of origin. It provides an explanation for the bi/multiracial women's ability to straddle two different and opposing cultures, providing some understanding of the chameleon-like changes necessary for a hybrid. (p. 503).

Grennell (2014) expands on this and further describes this opening of the third space as a liberating space where individuals can be who they wish without having to fit into the essentialised cultural identification. However, she goes on to say that the negotiation of hybridity is ongoing, daily and tiring. No matter how much the individual may experience themselves as hybrid, the individual is subjected to positioning themselves with one or the other by external pressures. 
To exclude one's self from positioning is itself a position that requires resistance to maintain, and in not choosing between one or the other position the individual may exist in a state of discomfort (Grennell, 2014). I am not wanting to put this Pacific community at discomfort so rather than label them as a hybrid identity, I prefer to coin a new term 'blended' that describes them in a less harmful light, and that acknowledges the differences of culture and race in a respectful way.

\section{Blended Background}

It is important to state at this point why I have not used the term hybrid identity and instead, used the term 'blended background'. Bolatagici (2004) states that this specific term, 'hybrid identity', is used to describe the identity of an individual who identifies with more than one culture, however in my research I am focusing on a community that identifies with more than one culture and race and that these different entities are separate but also relate, and that they hold distinct significance to the individual identity, in the Unity-that-is- All (Wendt, 1996).

I have used the term 'blended' as it is not specific to multiple cultural identities but inhabits the blend of mixed culture, mixed race, and mixed ethnicity. Blended speaks of a Pacific community that identifies with many of these identities, and is able to weave (lalaga) and bind (lalava) their individual 
identity, as they negotiate and re-negotiate their own lived ways of being. What I do acknowledge is that I agree with Bhabha (1994) hybridity speaks of a third space, thou this third space I have conceptualised as the vā.

The term 'blended backgrounds' I refer to in my research speaks of the up-coming generations of Pacific diaspora youth in Aotearoa/New Zealand. The statistics presented describe a growing community of individuals with multiple ethnicities. Spoonley (2000) in his article 'Reinventing Polynesia: The Cultural Politics of Transnational Pacific Communities' recognises these changes in the Auckland community and speaks of the emerging change in terms of multiple identities.

The size and maturation of the Pacific communities in Auckland represents the opportunity for alternative and multiple readings of ethnic identity, new forms of association and new personal and communal biographies. It also means that the Pacific is here - in Auckland and New Zealand rather than a colonial other "out there" in either a geographical sense or as racialised problem within New Zealand civic society. New identity positions have begun to emerge in a New Zealand location, the fa'a Aukilani or fa'a Niu Sila as a variant on a "traditional" fa'a Sāmoa (Macpherson, 1997:93). Indeed, the notion of Sāmoan ess is largely a product of colonialism and migration (Macpherson, 1998:5). It is now also a product of the emerging sense of location and politics of identity of its New Zealand context. The same process is apparent, 
with important variations, amongst other Pacific communities (p. 12).

It is important to recognise these changes, and to understand that with regard to certain aspects, the term 'diaspora' may no longer apply to this community (Yamamoto, 1996), as it is constantly adapting to different ways of living and raising questions about culture and the environment we live in.

In conclusion, the use of the term 'blended background' can be seen to reflect and emphasise a number of dynamics. It exists in a particular historical and political context. While it allows for children and families to identify as being something other than a presumed norm, it reinforces the 'otherness', by presenting 'cultural identity' as something that is not singular, fixed, obvious and intrinsic to the individual. In this way, 'blended background' is the best option at present as it speaks of the many complexities and layers to identity. It is culturally sensitive and does not allow for racist ideas about the nature of cultural identities.

\section{Meaalofa}

Tagoilelagi (1995) stresses that reciprocity is encoded within fa'aSāmoa. Meaalofa is the general term that Sāmoans use to mean 'a gift'. Meaalofa literally means 'a thing of love'. Sāmoans use gifts 
as gestures of appreciation, respect, love, acknowledgement, and confirmation of special relationships. While the term is synonymous with the kind of gifting that takes place within all Pacific cultures in Aotearoa/New Zealand, Sāmoans see meaalofa as a physical embodiment of the giver's feelings towards the receiver. Sāmoans believe that there is a close spiritual, emotional and genealogical connection that takes place between the giver and receiver of the gift (William, 2006). Therefore, this research may be understood as a meaalofa, a respectful giving. It is a creative blend of knowledge that has been shaped by the generosity of culturallypositioned thinkers, and my work is returned to them and to the wider community. Toluta'u (2015a) expands on this thought and states:

While this thesis within the academy may be traditionally understood as a scholar's independent contribution to knowledge I suggest that it may be considered in another way. Arguably, scholarship (including this thesis) might function as a respectful returning of processed thinking to a greater whole. In this regard the scholar is not a discrete, independent entity, but part of a community of though from which they receive gifts and to which they return gifts. In doing so they draw on past to contribute to the future. Thus, their thinking, education, inspiration and responsibility function as part of a greater construct of shaped experience.(p.4) 
Toluta'u describes the process of formulating her thesis as a collective piece, gifted from the knowledge of others as well as her own. Her thesis is the result of the reciprocity of knowledge that has been given, then gifted back to her community. Like Toluta'u, this thesis is my gift, my appreciation of respect and love, my acknowledgement and confirmation of the special relationship I have with all of the knowledge and lessons that have been gifted to me. Therefore, the reciprocity act encoded within fa'aSāmoa will be lifted upon completion of this research.

\section{Conclusion}

In this article, a review of the literature found that there are common themes of vā in fa'asāmoa and within Pacific cultural beliefs about identity in the diaspora. The theme of vā stresses the importance of considering and incorporating aspects of fa'aSāmoa and into attempts to provide a spatial design that is culturally sensitive to traditional beliefs and knowledge. Reflecting on the design proposal, it needs to explore the strengths of vā through Pacific cultures in successive generations of Pacific peoples living in Western countries, and the ways in which Pacific people draw on traditional and Western ways to sustain their culture in the diaspora. 
The design proposal needs to acknowledge the changes of identity that have occurred in the diasporic communities, whilst providing a space for vā relations to occur; a safe natural space for youth to connect with their Pacific culture(s) on their own terms, a space where there is no obligation or pressure to choose your preferred culture or identity, and where there is no tension, confusion, and cultural cringe (Tiatia, 1998).

The vā relations, from my own experience, are still very much active within Aotearoa Pacific communities in Aotearoa/New Zealand. Therefore, what I propose is not just a design offering a space for these vā relations, but an intervention where these relations are stirred (ala-vā means literally 'stirring the vā') to form further connections with multiple cultures and communities. These can also include metaphorical connections of locations from the diaspora (our current living sites) in Western countries, to the Pacific Islands.

Having now outlined significant literature impacting the research question, it is useful to examine the thoughts and ideas for this research, from the community participants. 


\section{References}

Aiono, F. (1997). O le fa'asinomaga: Le tagata ma lona fa'asinamaga. Alafua, Samoa: Lamepa Press.

Allen, A. E. G. (1993). Space as social construct: the vernacular architecture of rural Samoa. Columbia University.

Anae, M. (1997). Towards a NZ-born Samoan identity: Some reflections on "labels.". Pacific Health Dialog, 4(2), 128-137.

Anae, M. (1998a). Fofoa-i-vao-'ese: the identity journeys of NZ-born Samoans. ResearchSpace@ Auckland.

Anae, M. (1998b). The identity journeys of NZ-born Samoans. The University of Auckland, Auckland. Retrieved from https://researchspace.auckland.ac.nz/handle/229 $\underline{2 / 66}$

Anae, M. (2000). Samoans - History and migration. Te Ara - the Encyclopedia of New Zealand. Retrieved from http://www.TeAra.govt.nz/en/samoans/1 Anae, M. (2001). To be or not to be... Samoan: NZborn Samoan identity journey experiences. presented at the meeting of the Paper presented at the Measina a Samoa Conference, Apia, Samoa.

Anae, M. (2002). Papalagi Redefined: Toward a New Zealand-Born Samoan Identity. Pacific Diaspora: Island Peoples in the United States and Across the Pacific, University of Hawaii Press, Honolulu, 150168. 
Anae, M. (2009). Samoans - New Zealand-born identity Te Ara - the Encyclopedia of New Zealand: Ministry for Culture and Heritage / Te Manatū Taonga.

Arendt, H. (2013). The human condition: University of Chicago Press.

Auckland Museum. (2011). Pacific Lifeways. Retrieved from http://www.aucklandmuseum.com/?t=298

Bancroft, H. (1900). New Pacific. New York: The Bancroft Company.

Bhabha, H. K. (1994). The location of culture: Psychology Press.

Bolatagici, T. (2004). Claiming the $(\mathrm{N})$ either/(N) or of 'Third Space':(re) presenting hybrid identity and the embodiment of mixed race. Journal of intercultural studies, 25(1), 75-85.

Brettell, C. B. (2003). Anthropology of migration: Wiley Online Library.

Calvet, L.-J. (1994). Les voix de la ville: Introduction à la sociolinguistique urbaine: Payot.

Candy, L. (2006). Practice based research: A guide. CCS Report, 1, 1-19. Retrieved from http://www.mangold-

international.com/fileadmin/Media/References/Pu blications/Downloads/Practice_Based_Research_A

Guide.pdf

Clayton, L. (2007). Patterns and motifs in the va: a Samoan concept of a space between. Auckland University of Technology. Retrieved from 
http://aut.lconz.ac.nz/vwebv/holdingsInfo?bibId= 1061322

Clifford, J. (1997). Routes: travel and translation in the late twentieth century. Cambridge, Mass: Harvard University Press. Retrieved from http://aut.summon.serialssolutions.com/2.0.0/lin k/0/eLvHCXMwY2BQSDYyTzQHdneMklNNzZIMLV JTLY2SDdOSTcxSjFNNk1JQxnORSnM3IQam1DxR Bik31xBnD93E0pJ46BgGqIFqbGJpbCjGwJsIWvm dVwLeIZYiwaBgZmRpYZRsnmSZYmlokmxiaZGUa mGZmmZiamhslpRoYAgA740kcA

Clifford, J. (2007). Varieties of indigenous experience: Diasporas, homelands, sovereignties. Indigenous experience today, 197-223.

Cochrane, S. (2001). Bérétara: Contemporary Pacific Art: Halstead.

Collins, S. (May 30, 2008). Pacific kiwis losing mother tongues. New Zealand Herald. Retrieved from

http://www.nzherald.co.nz/nz/news/article.cfm?c id $=1 \&$ objectid $=10513387$

Cook, L., Didham, R., \& Khawaja, M. (2001). The shape of the future: On the demography of Pacific Peoples. In P. S. C. Macpherson, M. Anae (Ed.), Tangata o te moana nui: The evolving identities of pacific peoples in Aotearoa/New Zealand (pp. 4465). Palmerston North: Dunmore Press.

Crocombe, R. G. (1973). The New South Pacific: Reed education. 
Duranti, A. (1997). Indexical speech across Samoan communities. American Anthropologist, 342-354.

Fairbairn-Dunlop, P. (1996). Tamaitai Samoa Their Stories. Suva: KIN Publications.

Feu'u, F. (1995). Samoan Artists in Samoa and New Zealand. Art and Asia Pacific, 2(4), 61-67.

Flick, U., Kardorff, E. v., \& Steinke, I. (2004). A companion to qualitative research. London: SAGE.

Furnas, J. C. (1945). Anatomy of Paradise: Hawaii and the island of the south seas. New York: Sloane. Gardiner, S. (2006). Binary Code Art News Zealand, 53.

Gegeo, D. W., \& Watson-Gegeo, K. A. (2001). "How We Know": Kwara'ae Rural Villagers Doing Indigenous Epistemology. On The Contemporary Pacific: University of Hawai'i Press. Retrieved from http://muse.jhu.edu/journals/contemporary_pacif ic/v013/13.1gegeo01.html

Gegeo, D. W., \& Watson-Gegeo, K. A. (2002). Whose knowledge?: Epistemological collisions in Solomon Islands community development. The Contemporary Pacific, 14(2), 377-409.

Geoff, W. (2006). Doing interpretive research. European Journal of Information Systems, 15(3), 320-330. doi:10.1057/palgrave.ejis.3000589

Georgiou, M. (2001). Thinking Diaspora: Why Diaspora is a Key Concept for Understanding Multicultural Europe. On-Line/More Colour in the Media: THE MULTICULTURAL SKYSCRAPER NEWSLETTER Vol. 1 No. 4. Tuesday, December 4. 
Online: retrieved 2008-02-01 from http://www. multicultural. net/index. asp.

Georgiou, M. (2007). Transnational crossroads for media and diaspora: Three challenges for research: Palgrave Macmillan.

Gershon, I. (2007). Viewing Diasporas from the Pacific: What Pacific Ethnographies Offer Pacific Diaspora Studies. The Contemporary Pacific, 19(2), 474-502. doi:10.1353/cp.2007.0050

Gershon, I. (2012). No family is an island: cultural expertise among Samoans in diaspora. Ithaca: Cornell University Press. Retrieved from http://aut.summon.serialssolutions.com/2.0.0/lin k/0/eLvHCXMwA20DTrMwSzNLBNZMaSlpBqkpSS kpwHQErNkMOkyTIIdoI8ZzkUpzNyE

Grennell, N. (2014). What is the experience of being both Māori and Pākehā? Negotiating the experience of the hybrid cultural object.

Griffiths, M. (2010). Research and the self. In M. Biggs, \& Karlsson, H. (Ed.), The Routledge companion to research in the arts (pp. 167-185): Routledge.

Gunn, M. (2006). Fragments of history. In C. M. Geary (Ed.), From the South Seas: oceanic art in the Teel Collection (pp. 11-17). Boston: MA:MFA Publications.

Halapua, S. (2000). Talanoa process: The case of Fiji. East West Centre, Hawaii. 
Hall, S., Morley, D., \& Chen, K.-H. (Eds.). (1996). Stuart Hall critical dialogues in cultural studies. London: Routledge.

Hatch, J. A. (2002). Doing Qualitative Research in Education Settings: State University of New York Press.

Hau'ofa, E. (1994). Our sea of islands. The Contemporary Pacific, 148-161.

Howard, D., Shaw, M., Hoddell, S., Street, D., \& Wildblood, H. (2002). Doctorates-converging or diverging patterns of provision. Quality Assurance in Education, 10(2), 61-70.

Jackson, P., Crang, P., \& Dwyer, C. (2004). Transnational spaces: London ; New York : Routledge.

Ka'ai-Mahuta, R. (2010). He kupu tuku iho mō tēnei reanga: A critical analysis of waiata and haka as commentaries and archives of Mãori political history. Auckland University of Technology, Auckland University of Technology.

Ka'ili, T. (2005). Tauhi va: nurturing Tongan sociospatial ties in Maui and beyond (Vol. 17): University of Hawaii Press. Retrieved from http://aut.summon.serialssolutions.com/2.0.0/lin k/0/eLvHCXMwzZ1LT8JAEMc3hpM3H_jWzIkLIYZ u2VITY4zR4MFwoJzJsN3oHlwSbCF8e

Ka'ili, T. (2008). Tauhi va: Creating beauty through the art of sociospatial relations. University of Washington. 
Keddell, E. (2006). Pavlova and pineapple pie: Selected identity influences on Samoan-Pakeha people in Aotearoa/New Zealand. Kōtuitui: New Zealand Journal of Social Sciences Online, 1(1), 4563.

Keesing, F. M. (1934). Modern Samoa. Its Government and Changing Life.

Kirshenblatt- Gimblett, B. (2000). Exhibiting the Other: Museums of Mankind and the Politics of Culture Representation. Reflections.

Kirshenblatt- Gimblett, B. (2002). The Dematerialization of culture and the DeAccessioning of Museum collections. Museum International, 54(4), 58-63.

Kroll, J. (2004). The exegesis and the gentle reader/writer. School of Arts, Griffith University. Retrieved from http://www.textjournal.com.au/speciss/issue3/kr oll.htm

Lewis, M. W. (2010). Cultural Disparity and Political Solidarity in the Melanesian Island World [Map]. Retrieved from http://www.geocurrents.info/geopolitics/culturaldisparity-and-political-solidarity-in-themelanesian-island-world Lilomaiava-Doktor, S. (2009). Beyond "Migration": Samoan Population Movement (Malaga) and the Geography of Social Space (Va) The Contemporary Pacific, 21(1). 
Linnekin, J., \& Poyer, L. (1990). Cultural identity and ethnicity in the Pacific: University of Hawaii Press.

Logan, I. (May-June, 2006). Labour forces. Spasifik magazine, 14, 12-15.

Macpherson, C. (2004). From Pacific Islanders to Pacific people and beyond. Spoonley P., Macpherson C. et Pearson D.(éds.), 135-155.

Macpherson, C., \& Bedford, R. D. (1999, October 20). The Structured Roots of Transformation of Pacific Identity in Aotearoa. presented at the meeting of the Out of Oceania Conference, Hawai'i.

Mageo, J. M. (1998). Theorizing self in Samoa: Emotions, genders, and sexualities: University of Michigan Press.

Mallon, S. (2002). Samoan art and artists: O measina a Samoa. Nelson, N.Z: Craig Potton. Retrieved from http://aut.lconz.ac.nz/vwebv/holdingsInfo?bibId= $\underline{22476}$

Mallon, S., \& Pereira, P. F. (1997). Speaking in colour: conversations with artists of Pacific Island heritage. Wellington [N.Z.]: Te Papa Press.

Manu, P. (2013). Spaces between: a personal exploration of the $V \bar{A}$. Auckland University of Technology Retrieved from http://aut.summon.serialssolutions.com/2.0.0/lin k/0/eLvHCXMwY2BQSDQzSEs2MkgytUgBtm6Tks wTE1PTU1OSzVISkw2Nk5NRx3MZYNfVoR0tAKz5LI $\underline{30 T S 1 B-}$ 
Marshall, C., \& Rossman, G. B. (2014). Designing qualitative research: Sage publications.

Maxwell, J. A. (2013). Qualitative research design: an interactive approach (Vol. 41). Thousand Oaks, Calif: SAGE Publications.

McCarthy, F. L. (2005). New Zealand's Pacific Advantage. In J. a. W. Henderson, G. (Ed.), Securing a Peaceful Pacific (pp. 43-49): Canterbury University Press

McGrath, B. B. (2002). Seattle" Fa'a Sāmoa". The Contemporary Pacific, 307-340.

Meleisea, M. (1987). The making of modern Samoa: traditional authority and colonial administration in the history of Western Samoa: editorips@ usp. ac. fj. Merriam, S. B. (2009). Qualitative research: a guide to design and implementation. San Francisco, Calif: Jossey-Bass.

Mila-Schaaf, K. (2006). Va-centred social work: Possibilities for a Pacific approach to social work practice. Social Work Review, 18(1), 8.

Mila-Schaaf, K., \& Hudson, M. (2009). The interface between cultural understandings: Negotiating new spaces for Pacific mental health. Pacific health dialog, 15(1), 113-119.

Ministry of Social Development. (2005). Pacific youth development strategy: Deliver positive life-change and affirmation for all Pacific youth in Auckland. Auckland, New Zealand: Ministry of Social Development. 
Moeke-Maxwell, T. (2005). Bi/multiracial Maori women's hybridity in Aotearoa/New Zealand. Discourse: studies in the cultural politics of education, 26(4), 497-510.

Morton, H. (1998). Creating Their Own Culture: Diasporic Tongans. The Contemporary Pacific, 10(1), 1-30.

Newbury, D. (2001). Diaries and fieldnotes in the research process. Research issues in art design and media, 1, 1-17.

Ochs, E. (1988). Culture and language development: Language acquisition and language socialization in a Samoan village: CUP Archive.

Papoutsaki, E., \& Strickland, N. (2008). Pacific islands diaspora media: Sustaining island identities away from home.

Park, K. (1997). The Korean American dream: Immigrants and small business in New York city: Cornell University Press.

Pereira, P. F. (2002). Identities Adorned: Jewellery and Adornments. In S. Mallon \& P. F. Pereira (Eds.), Pacific Art Niu Sila: The Pacific Dimension of Contemporary New Zealand Arts (pp. 39-51): Wellington: Te Papa Press.

Perrott, A. (2007). Pacifika: Identity or Ilussion. Canvas, Weekend Herald, pg, 8-11.

Portes, A., \& Rumbaut, R. G. (2001). Legacies: The story of the immigrant second generation: Univ of California Press. 
Pratt, G. (1893). A grammar and dictionary of the Samoan language: with English and Samoan vocabulary: London Missionary Society.

Puaina, S., Aga, D. F., Pouesi, D., \& Hubbell, F. A. (2008). Impact of traditional Samoan lifestyle (fa'aSamoa) on cancer screening practices. Cancer detection and prevention, 32(1), 23-28.

Pulotu-Endemann, F. K., \& Tu'itahi, S. (2009). Fonofale: Model of Health

Refiti, A. (2008b). Forked Centre: duality and privacy in Polynesian spaces and architecture. AlterNative: An International Journal of Indigenous Peoples, 4(1), 97-106.

Robie, D. (2009). Diversity reportage in Aotearoa: Demographics and the rise of the ethnic media.

Rouse, M. (2015). Social Media. Retrieved January 12 , 2015 , from http://whatis.techtarget.com/definition/socialmedia

Sa'iliemanu, L.-D. (2009). Beyond Migration: Samoan Population Movement (Malaga) and the Geography of Social Space (Vā). The Contemporary Pacific, 21(1), 1-32.

Salesa, D. (2005). Misimoa. 5. Retrieved from http://www.common-place.org/vol-05/no02/salesa/index.shtml

Sawicka, T., Barr, K., Grace, D., Grenside, L., Thomson, J., \& Williams, G. (2007). Forming a cultural identity: What does it mean to be ethnic: Retrieved. 
Schoeffel, P. (1999). Samoan Exchange and 'Fine Mats': An Historical Reconsideration. The Journal of the Polynesian Society, 108(2), 177-148.

Scrivener, S. (2000). Reflection in and on action and practice in creative-production doctoral projects in art and design. Working Papers in art and design, 1. Shore, B. (1982). Sala'ilua-A Samoan Mystery: Columbia University Press.

Simati-Kumar, B. (2012a). The Potential of Vātransforming Samoan and Pacific communities in the Diaspora. Te Kaharoa: The eJournal of Indigenous Pacific Issues, 11.

Simati-Kumar, B. (2012b). The potential of Vā: an investigation of how 'Ie Tóga activate the spatial relationships of the Vā, for a Samoan diaspora community. AUT University, Auckland. Retrieved from http://hdl.handle.net/10292/4431

Smith, L. T. (1999). Decolonizing methodologies: research and indigenous peoples. Dunedin, N.Z: Zed Books.

Soanes, C., \& Stevenson, A. (Eds.). (2008). Concise oxford english dictionary. New York: NY: Oxford University Press.

Spickard, P. R., Rondilla, J. L., \& Hippolite Wright, D. (2002). Pacific diaspora: island peoples in the United States and across the Pacific. Honolulu: University of Hawai'i Press.

Spoonley, P. (2000). Reinventing Polynesia: The cultural politics of transnational Pacific communities: 
University of Oxford. Transnational Communities Programme.

Statistics New Zealand. (2007). QuickStats About Culture and Identity: 2006 Census Data. Wellington: Statistics New Zealand.

Statistics New Zealand. (2014). 2013 Census QuickStats about culture and identity. Retrieved from http://www.stats.govt.nz/Census/2013census/profile-and-summary-reports/quickstatsculture-identity.aspx

Statistics New Zealand. (2015). Statistical standard for ethnicity. Retrieved from http://m.stats.govt.nz/methods/classificationsand-standards/classification-related-statsstandards/ethnicity

Stevenson, K. (1996). Culture and Identity: Contemporary Pacific Artists in New Zealand. Bulletin of New Zealand Art History, 17, 59-68. Stevenson, K. (2000). Another Introduced Species? Michel Tuffery: An Artist with a Conscience: Christchurch: PAC RIM Print.

Stevenson, R., L. (1996). A footnote to history: Eight years of trouble in Samoa. Auckland: Pasifika press. Tagoilelagi, F. a. F. (1995). The role of the Samoan culture (fa'asamoa) in the development of its childrens' literacy skills.

Tamasese, K., Peteru, C., \& Waldegrave, C. (1997). Ole Taeao Afua, the new morning: a qualitative investigation into Samoan perspectives on mental health and culturally appropriate services. 
Australian and New Zealand Journal of Psychiatry, 301-309.

Teaiwa, T., \& Mallon, S. (2005). Ambivalent Kinships? Pacific People in New Zealand. New Zealand identities: Departures and destinations, 207-229.

Thrasher, F. M., \& Short, J. F. (1963). The gang: A study of 1,313 gangs in Chicago: University of Chicago Press.

Tiatia, J. (1998). Caught between cultures: a New Zealand-born Pacific Island perspective: Christian Research Association.

Tohi, F. (2006). Sopolemalama Art of lalava. Retrieved 19 March 2010, from http://www.lalava.net/nav.html

Toluta'u, T. K. (2015a). Veitalatala: Matanga 'o e Talanoa. Auckland University of Technology, Auckland University of Technology.

Toluta'u, T. K. (2015b). Veitalatala: Matanga 'oe Talanoa. Auckland University of Technology.

Tsagarousianou, R. (2002). Ethnic community media, community identity and citizenship. In N. J. a. O. Prehn (Ed.), Community Media in the Information Age: Perspectives, Findings and Policy. New Jersey: Hampton Press.

Tuagalu, I. (2009). Heuristics of the Vā. AlterNative: An International Journal of Indigenous Peoples, 4(1), 107-126.

Tupuola, A. M. (2004). Pasifika Edgewalkers: complicating the achieved identity status in youth 
research. Journal of intercultural studies, 25(1), 87100.

Vaioleti, T. M. (2006). Talanoa research methodology: a developing position on pacific research. Waikato Journal of Education, 12, 21-34.

Vivieaere, J. (1994). Bottled Ocean. Wellington: Wellington City Gallery.

Wendt, A. (1996). New Zealand electronic poetry centre. Tatauing the post-colonial body, span 42-43, 15-29.

Retrieved

from

http://www.nzepc.auckland.ac.nz/authors/wendt tatauing.asp.

Whimp, G. (2009). Working in the Space Between: Pacific Artists in Aotearoa/New Zealand: University of Hawai'i at Mānoa. Retrieved from http://hdl.handle.net/10125/14680

William, S. S. (2006). A Personal Summary of Samoa's gifting custom. Retrieved 30/09/2015, from

http://media.apn.co.nz/webcontent/document/pd f/samoan_gifting.pdf

Yamamoto, M. (1996). Samoan Diaspora and Ceremonial Exchange. Retrieved 15 August 2011, 2010, from http://www.t.hosei.ac.jp/ matoriy/paper/migrant. $\underline{\text { htm }}$ 